29 R Development Core Team. R: A Language and Environment for Statistical Computing. R Foundation for Statistical Computing, 2010.

30 Bodis-Wollner I, Yahr MD. Measurements of visual evoked potentials in Parkinson's disease. Brain 1978; 101: 661-71.

31 Bodis-Wollner I, Marx MS, Mitra S, Bobak P, Mylin L, Yahr M. Visual dysfunction in Parkinson's disease. Loss in spatiotemporal contrast sensitivity. Brain 1987; 110: 1675-98.

32 Glover A, Ghilardi MF, Bodis-Wollner I, Onofrj M. Alterations in event-related potentials (ERPS) of MPTP-treated monkeys. Electroencephalogr Clin Neurophysiol 1988; 71: 461-8.

33 Langheinrich $\mathrm{T}$, Tebartz van Elst, Lagrèze WA, Bach $\mathrm{M}$, Lücking $\mathrm{CH}$, Greenlee MW. Visual contrast response functions in Parkinson's disease: evidence from electroretinograms, visually evoked potentials and psychophysics. Clin Neurophysiol 2000; 111: 66-74.

34 luvone PM, Galli CL, Garrison-Gund CK, Neff NH. Light stimulates tyrosine hydroxylase activity and dopamine synthesis in retinal amacrine neurons. Science 1978; 202: 901-2.

35 Djamgoz MB, Hankins MW, Hirano J, Archer SN. Neurobiology of retinal dopamine in relation to degenerative states of the tissue. Vision Res 1997; 37: 3509-29.

36 Ebert D, Feistel H, Kaschka W, Barocka A, Pirner A. Single photon emission computerized tomography assessment of cerebral dopamine D2 receptor blockade in depression before and after sleep deprivation-preliminary results. Biol Psychiatry 1994; 35: 880-5.

37 Hamilton JP, Chen G, Thomason ME, Schwartz ME, Gotlib IH. Investigating neural primacy in major depressive disorder: multivariate Granger causality analysis of resting-state fMRI time-series data. Mol Psychiatry 2011; 16: $763-72$

38 Saijo $\mathrm{T}$, Takano A, Suhara $\mathrm{T}$, Arakawa $\mathrm{R}$, Okumura $\mathrm{M}$, Ichimiya $\mathrm{T}$, et al. Electroconvulsive therapy decreases dopamine $D_{2}$ receptor binding in the anterior cingulate in patients with depression: a controlled study using positron emission tomography with radioligand $\left[{ }^{11} \mathrm{C}\right] \mathrm{FLB} 457$. J Clin Psychiatry 2010; 71: 793-9.

39 Pei L, Li S, Wang M, Diwan M, Anisman H, Fletcher PJ, et al. Uncoupling the dopamine D1-D2 receptor complex exerts antidepressant-like effects. Nat Med 2010; 16: 1393-5.

40 Schilström B, Konradsson-Geuken A, Ivanov V, Gertow J, Feltmann K, Marcus $\mathrm{MM}$, et al. Effects of S-citalopram, citalopram, and R-citalopram on the firing patterns of dopamine neurons in the ventral tegmental area, N-methyl-Daspartate receptor-mediated transmission in the medial prefrontal cortex and cognitive function in the rat. Synapse 2011; 65: 357-67.

41 Seggie J, Canny C, Mai F, McCrank E, Waring E. Antidepressant medication reverses increased sensitivity to light in depression: preliminary report. Prog Neuropsychopharmacol Biol Psychiatry 1989; 13: 537-41.

42 Volkow ND, Wang G-J, Telang F, Fowler JS, Logan J, Wong C, et al. Sleep deprivation decreases binding of [11C]raclopride to dopamine D2/D3 receptors in the human brain. J Neurosci 2008; 28: 8454-61.

43 Friedman J, Meares R. The effect of placebo and tricyclic antidepressants on cortical evoked potentials in depressed patients. Biol Psychol 1979; 8: 291-302.

\title{
Easy Listening
}

\section{Dino Campana}

I seek no peace, and cannot stand war I dream my way around the world, quiet and alone

Brimming with muted songs. I long

For the fog and silence of a great port

A great port crowded with light sails

Ready to leave towards the blue horizon

Wavering softly as the whispering wind rises

And sings its brief chords on its way.

And those chords are carried by the wind

Far away over the unknown sea

- I'm dreaming. Life is sad and I'm alone

When, when will my soul awaken in the sun

Shivering with freedom in a morning bright with fire

Awaken in the sun, the eternal sun.

This poem is from Dino Campana's (1885-1932) Selected Works, translated by Cristina Viti and published by Survivors' Poetry in 2006. Dino Campana was admitted to San Salvi, an asylum in Florence at the age of 32 years and transferred to Castel Pulci, a place designated for those regarded as incurable in April 1918 where he remained until his death.

Chosen by Femi Oyebode. 